\title{
Entrepreneurial specific characteristics and access to finance of SMEs in Khyber Pakhtunkhwa, Pakistan
}

\section{Suhail Ahmad ${ }^{\mathrm{a}}$}

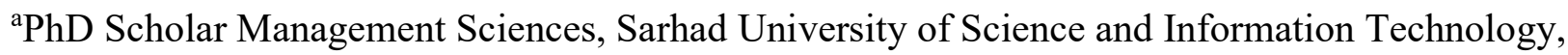
Peshawar Khyber Pakhtunkhwa, Pakistan. suhail.shm8@gmail.com

\section{S. Ghiasul Haq}

${ }^{b}$ Dean Faculty of Management Sciences, Sarhad University of Science and Information Technology, Peshawar Khyber Pakhtunkhwa, Pakistan. suhailahmad.kmu@gmail.com

\section{Tahar Tayachi ${ }^{\mathrm{c}, \mathrm{d}}$}

${ }^{c}$ Chair Department of Finance, Effat University, KSA ttayachi@effatuniversity.edu.sa +966543168479 ,

${ }^{\mathrm{d}}$ FSEG Mahdia, University of Monastir, 5100, Mahdia, Tunisia.

\begin{abstract}
ABSTARCT
Small and medium-sized enterprises (SMEs) help and support the country in financial and business aspects and employs in the country, overcomes unemployment, and creates job opportunities in different sectors of the country. The study aims to know the entrepreneurial-specific factors like age, gender, education, experience, and skills used as predictors for access to financing of small firms in Khyber Pakhtunkhwa. The questionnaire is used for data collection, and about 204 questionnaires were distributed, of which 192 returned and analyzed through binary logistic regression. The study results reveal that age and level of education have been found significant while gender, experience and skills have insignificant with the access to finance in Khyber Pakhtunkhwa, Pakistan.
\end{abstract}

Keywords: SMEs, Access to finance, SME's entrepreneur, Entrepreneurial characteristics, Pakistan.

\section{Introduction}

SMEs role cannot be ignored in the economy of both developed and developing countries across the regions. In a developed country such as Australia, SMEs serve as a means of reviving stagnant industries (Ahmad, 2007; Thomas \& Mueller, 2000). The importance of a healthy industrial sector cannot be overlooked; in the last two centuries, industrial production has been the main impetus for productivity and improved quality of life in developed countries (Murphy, Shleifer, \& Vishny, 1989). According to European Commission 2011 report stated that countries that have not successfully industrial development remain poor, SMEs as the backbone of any economy around the world for their significant contribution. The US small business comprises $99.7 \%$ of all employer firms, employing half of all private sectors, which gained sixty to eighty percent of its new jobs per year from last ten years, generates more than 50 percent of the non-governmental private GDP (Mijid, 2009). 
Small businesses are an integral part of an economy. Data and reports from the SME subgroup also indicate that SMEs in developing countries also contribute significantly to employment and a $45 \%$ contribution to an annual 33\% gross domestic product (Nguyen \& Luu, 2013). The financial needs and practices of SMEs must first be considered, as these institutions are important for development of most economies around the world. They have contributed significantly to the development of economies of the countries and the creation of employment opportunities (Bank Niagara Malaysia, 2007). In addition, they made valuable contributions to regional income and savings, facilitate training, and create a competitive edge by helping large firms and therefore be the stimulus for economic growth and development (Hall, 2002). The enrichment and development of SMEs have significantly helped not only in generating job opportunities but also in reducing poverty (Abdullah et al., 2011; UNDP, 2007).

In Pakistan, SMEs own 90\% of all companies, including the textile industry (Arshad \& Arshad, 2019; Budhi, Lestari, Suasih, \& Wijaya, 2020). SMEs also play a vital role in Indonesia's national economy. It is evident by the different small businesses up to 62.9 million units, which reaches $99.99 \%$ with a unit share, compared to the large firms, which are 5,460 units with a $0.01 \%$ unit share in 2017(Budhi et al., 2020). In Jordan, the government believes that human, social and economic development depends on MSMEs. The national agenda of 2006-2015; helps MSMEs as a strategy to improve social security and well-being and promote economic development. In Jordan, SMEs face various problems, such as a lack of credit history, which impede their growth and development.

The financing as an important for SMEs' success. In Thailand, small firms share up to forty percent of GDP in 2008, and more than seventy-five percent of the jobs in 2013. In Vietnam, small businesses contributed $40 \%$ to GDP, and profits increased by about $20 \%$ annually (Muenjohn \& McMurray, 2017). The importance of the rapid development of small businesses in all regions of Russia is explained for the period up to 2030 (Development Strategy, 2016). It is shown that from 2015 to 2016, the number of small businesses and employees increased at the same time (Pinkovtskaia, Balynin, Arbeláez Campillo, \& Rojas-Bahamón, 2019). However, several studies have pointed out obstacles to SMEs in their development across different regions such as financial constraints, marketing, technology, innovation, HR practices, skilled personnel, bureaucracy and regulations of the regulatory authorities (Assimakopoulos \& Mitussis, 2010; Harvies, 2008).

\subsection{Objectives of the Study}

The research was attempting in this direction and proposed and developed a conceptual model for SMEs and their entrepreneurial characteristics, and will see that what factors that influence the SMEs are financing patterns and accessibility of loan and credit for their operations and commercial purposes and success of SMEs across the globe; and seeks to know and determine the financing pattern of SMEs and access to loans, and the second is to investigate the entrepreneurspecific factors influencing access to finance in Khyber Pakhtunkhwa (KP). The paper is structured as in section 2 consist of literature review \& hypotheses followed by section 3 methodology \& data analysis and section 4 consist of discussion $\&$ conclusion followed by the reference list.

\section{Literature Review and Hypotheses Development}

Entrepreneurial specific features have impacted access to finance by SMEs and these are the personal traits of owner-manager of SMEs. A study in the UK \& the US point outs that SMEs' success is associated with education, age, net worth, and several years of work (Vos, Yeh, Carter, 
$\&$ Tagg, 2007). Discovering the personal values of owners and managers, the strategies they adopt when running their companies, and the results of their business performance are inwardly related whereas a positive relationship between owner-manager personal traits and business performance of SMEs (Nimalathasan, 2008). Previous literature suggests that financing factors for firms are owner characteristics, company characteristics, and ownership (Akoten, Sawada, \& Otsuka, 2006; Beck, 2007; Beck \& Demirguc-Kunt, 2006; Coleman, 2004; Le, Venkatesh, \& Nguyen, 2006; Nguyen \& Luu, 2013; Rand, 2007). The factors such as financial issues, including short and longterm loans, good access to infrastructure, reliable supply chain systems, work experience and educational background on the success of SMEs.

\subsection{Age of SME's entrepreneur}

Many studies have examined the access to loan and age of the owner-manager; however, some findings point to the importance of SME entrepreneur's age. Studies have shown that age does not have any association with access to finance (Fatoki \& Odeyemi, 2010; Nguyen \& Luu, 2013). On the other hand, a study found that the entrepreneur's age has positive impacts to bank loan accessibility (Ogubazghi \& Muturi, 2014). A study examined the financial behavior of SMEs using two datasets comprising 15,750 and 3,239 SMEs from the UK and the US, respectively. The results reveals that younger owners-manager use more bank loans, credit cards, savings and family resources than older who rely on income (Vos et al., 2007). The young owner had a better chance of survival in SMEs were considered being an old (Headd, 2003). Based on the literature, the proposed hypotheses will be as;

H1: The age of SME's owner-manager has a significant relation with access to loan.

H01: The age of SME's owner-manager has not a significant relation with access to loan.

\subsection{Gender of SME's entrepreneur}

The study found an association of gender and external finance access and reveals that both men and black and ethnic minority participants are inclined to the advice of family and friends, while women are more likely than men to use a business link (Irwin \& Scott, 2010b). A study by Watson, Newby, and Mahuka (2009) do not provide any evidence to suggest a financial gap in the small businesses in Australia. In addition, the study further found no gender differences treated by the financial institutions with respect to financing. A study in the USA examines how the views of SMEs owner-managers regarding the gender differences and getting loans. which resulted that business owners-managers and male and female partners of bankers had a higher confidence level to loan and banking knowledge (Saparito, Elam, \& Brush, 2013).

As the education factors including gender and ethnicity of owner-manager, the result shows that graduates had less difficulty obtaining funding than the college level. The women surveyed examined that raising of funds by female is easy than the male, and ethnic minority businesses, especially black owners, had the most difficulty obtaining financial assistance, which is why they resorted to financing(Irwin \& Scott, 2010a). Based on the literature, the following hypotheses test empirically.

H2: Gender of SME's owner-manager has a significant relation with access to loan. 
H02: Gender of SME's owner-manager has no relation with access to loan.

\subsection{Education of SME's entrepreneur}

It is suggested that the higher level of education tends towards a positive role in the access to credit from banks (Kasseeah \& Thoplan, 2012). It has been found that there is a positive association of owners' education level and loan availability (Slavec \& Prodan, 2012; Zarook, Rahman, \& Khanam, 2013). Similarly, a study used the level of education of senior managers and revealed a relation with access to loan (Ahmed \& Hamid, 2011). The impact of education level and training on indirect bank loan access through business trends was investigated. SMEs with an entrepreneur who has a professional level of education have the right to access credit through banks (Kira, 2013). Therefore, the researcher proposed the following hypotheses;

H3: Education of SME's Entrepreneur has a significant relation with access to loan.

H03: Education of SME's Entrepreneur has not a significant relation with access to loan.

\subsection{Professional experience and skills of SME's entrepreneur}

Experience is an important for the external financing form the formal and informal financial institutions (Coleman, 2004). In addition, business size, gender, and location of owners are important factors at the company level that influence companies' reliance on informal credibility. Finally, the level of economic development in the country has significant implications in reducing the everyday use of credibility (Yaldiz, Altunbas, \& Bazzana, 2011). Most companies relied heavily on prior knowledge and experience (Simpson, Tuck, \& Bellamy, 2004).

Managerial skills play its role in attaining the funding from formal and informal financing sources. A study clarified that previous experience and skills was associated with access to loan from external sources for SMEs (Nofsinger \& Wang, 2011). Experienced entrepreneur is perform well as compared to the less experienced entrepreneur in the SMEs, it is advisable to include experience in loan credibility (Gompers, Kovner, Lerner, \& Scharfstein, 2010). A significant relation has been proved in with management skills and experiences in Bangladeshi SMEs (Uddin \& Bose, 2013). Thus, the following hypotheses proposed;

H4: Experience of SME's Entrepreneur has a significant relation with access to loan.

H04: Experience of SME's Entrepreneur has not a significant relation with access to loan.

H5: Skills of SME entrepreneurs have a significant relation with access to loan.

H05: Skills of SME's Entrepreneur have not a significant relation with access to loan.

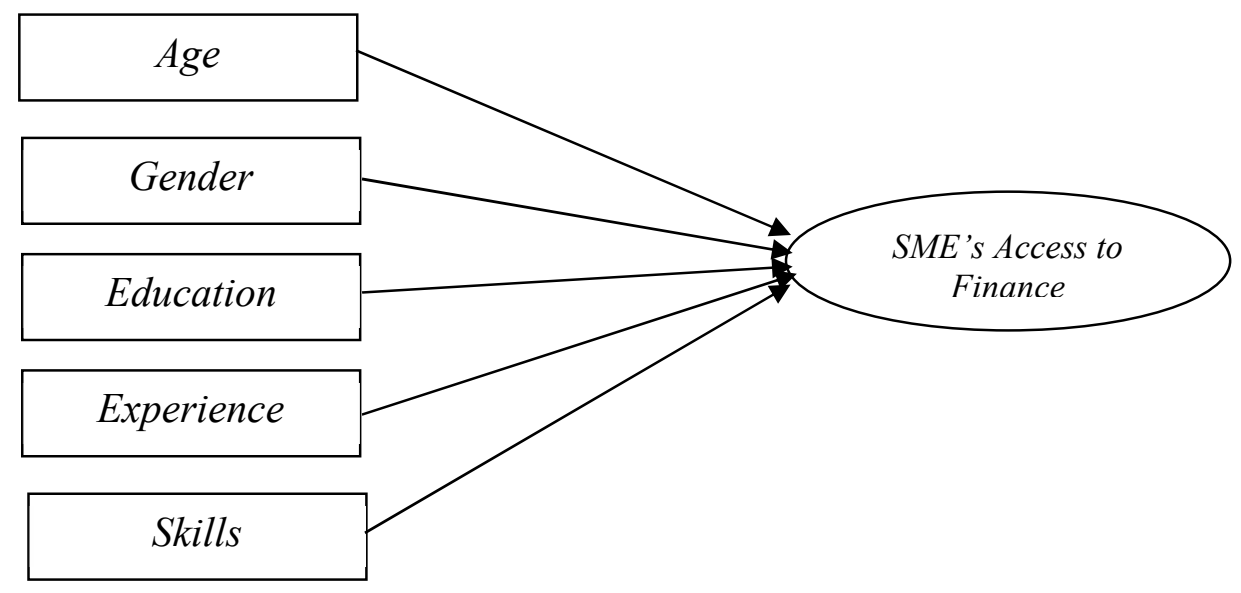


Fig.1. Conceptual Framework

\section{Methods}

\subsection{Binary Logistic Regression}

This type of regression is employed when predicting an association in variables. The dependent variables are binary, and having two choices (yes/no, male/female) and not more than that is termed as binary logistic. Binary logistics regression analysis is performed by multiple descriptive variables and the relationship between one single binary response variable, a categorical variable with two types (Sweet, 2011).

$\log \left(\mathrm{P}_{\mathrm{i}} / 1-\mathrm{P}_{\mathrm{i}}\right)=\mathrm{B}_{0}+\mathrm{B}_{1} \mathrm{X}_{1}+\mathrm{B}_{2} \mathrm{X}_{2}+\mathrm{B}_{3} \mathrm{X}_{3}+\mathrm{B}_{4} \mathrm{X}_{4}+\mathrm{B}_{5} \mathrm{X}_{5}+\ldots \ldots . \mathrm{Bk} \mathrm{X}_{\mathrm{k}}+\mathrm{E}$

Where $\log (\mathrm{P} / 1-\mathrm{P}=\log ($ likelihood $)$

$\mathrm{P}=\mathrm{e}^{\mathrm{a}+\mathrm{bx}} \div 1+\mathrm{e}^{\mathrm{a}+\mathrm{bx}}$

$\mathrm{P}=$ Target variable $(0$ to 1$)$

$\mathrm{B}_{0}=$ Constant

$\mathrm{B}_{1}=$ Coefficient of variable $\mathrm{X}_{1}$ and so on

$\mathrm{X}_{1}=$ Independent variable

$\mathrm{E}=$ Error term

Based on the above regression equation, the regression model of the study is as follows, i.e.

Access to finance $=\mathrm{B}_{0}+\mathrm{B}_{1}($ Age $)+\mathrm{B}_{2}($ Gender $)+\mathrm{B}_{3}($ Education $)+\mathrm{B}_{4}($ Experience $)+\mathrm{B}_{5}($ Skills $)+\mathrm{E}$

\subsection{Population and Data}

The population of the study is based on the SME sector of Khyber Pakhtunkhwa, Pakistan. There are different industrial zones in KP, which spread in Peshawar, Gadoon, Hattar, DI Khan, Swat, and other provinces. This study focused on the Peshawar district of the province, and it is the capital of the KP. The industrial zone is located in Hayatabad, the main city of capital and is the province's hub for business. The Hayatabad Industrial Sector has various kinds of industries and units of SMEs working. Therefore, the Hayatabad Industrial Sector is selected for data gathering and a total of 204 questionnaires distributed among the owner and manager of SMEs, in which 197 questionnaires returned, among which 192 used for data analysis (response rate is 94\%) and five were excluded due to the lack of data or missing the main section regarding the subject domain and only filled the demographic sections by the respondents.

\subsection{Variables of the study}


This section is comprised of the variables used in the study. Table 1 shows the details of the study variables, and there are one dependent variable and five explanatory variables that predict the dependent variable. The variable age and experience have six categories, followed by gender having two options, and level of education has four categories while both the skills and access to finance have two options in the questionnaire and details as shown in the following table 1.

\section{Table 1}

Variables Description

\begin{tabular}{|c|c|c|}
\hline S.No & Independent Variables & Option/Category \\
\hline \multirow{6}{*}{1} & Age & 1. 25-30 years \\
\hline & & 2. $30-35$ years \\
\hline & & 3. $35-40$ years \\
\hline & & 4. $40-50$ years \\
\hline & & 5. 50-55 years \\
\hline & & 6. $55-60$ years \\
\hline 2 & Gender & Male $=1$, Female $=0$ \\
\hline \multirow[t]{4}{*}{3} & Education & 1. School level \\
\hline & & 2. College level \\
\hline & & 3. University level \\
\hline & & 4. Diploma level \\
\hline \multirow[t]{6}{*}{4} & Experience & 1. $1-5$ years \\
\hline & & 2. 5-10 years \\
\hline & & 3. $10-15$ years \\
\hline & & 4. $15-20$ years \\
\hline & & 5. 20-25 years \\
\hline & & 6. 25-30 years \\
\hline 5 & Skills & $\mathrm{Yes}=1, \mathrm{No}=0$ \\
\hline S.No & Dependent variable & Option/Category \\
\hline 1 & Access to finance & Yes $=1, \mathrm{No}_{\mathrm{O}}=0$ \\
\hline
\end{tabular}

\section{Analysis and Results}

The data analyzed through binary logistic regression as the dependent variables (access to finance) is categorical and having two option (yes/no) and the explanatory variables are age, gender, education, experience, and skills. Therefore, binary logistic is suitable for analysis. Before analyzing, some assumptions are mandatory to check for the data and know whether the data is normally distributed or not, so the tests for normality are necessary.

Table 2 shows the Shapiro-Wilk test; if the value of significance is $>0.05$, then data is normally distributed; thus, the table indicated that the $\mathrm{P}$ values of each variable are greater than 0.05 , so it tells that the data is normal. 
Table 2

Tests of Normality

\begin{tabular}{lccc}
\hline & Shapiro-Wilk & & \\
& Statistic & df & Sig. \\
\hline Age & 0.907 & 192 & 0.484 \\
Gender & 0.572 & 192 & 0.613 \\
Education & 0.910 & 192 & 0.497 \\
Experience & 0.800 & 192 & 0.747 \\
Skills & 0.623 & 192 & 0.835 \\
Access to finance & 0.614 & 192 & 0.814 \\
\hline
\end{tabular}

Lilliefors Significance Correction

The assumption of collinearity also checks, and for this purpose, the tolerance and VIF is used to check collinearity of the data. If tolerance value is less than 0.1 or the VIF value is larger than five, there is a correlation between the variables (Midi, Sarkar, \& Rana, 2010).

Table 3 shows that the value of tolerance of each variable is greater than 0.1 , and the value of VIF is less than 5; thus, it means that the variables have no collinearity and feasible for logistic regression analysis.

\section{Table 3}

Multi-collinearity diagnosis indices

\section{Collinearity statistics}

\begin{tabular}{lcc}
\hline & Tolerance & VIF \\
\hline Age & 0.488 & 2.048 \\
Gender & 0.565 & 1.770 \\
Education & 0.799 & 1.252 \\
Experience & 0.962 & 1.040 \\
Do you have Skill? & 0.969 & 1.032 \\
\hline
\end{tabular}

Dependent Variable: Do you have access to loan?

Table 4 shows the output results of the dependent and explanatory variables of the study; according to the table, age $(\mathrm{P}<0.000$ and the value of the odds ratio are 5.488) is significantly associated with access to finance of SMEs, it means that if the age is increasing there is a 1.703 unit increases in the access to finance of the SMEs, therefore null hypothesis is rejected at $0.01 \%$ level of significance. Whenever the age of the entrepreneur (owner-manager) of SMEs is increasing, they know the business. They have seen many activities involving the business, including the financing and different strategies for the external funding opportunities for their business compared to the individual who has younger.

The education $(\mathrm{P}<0.040$ and the value of the odds ratio are 1.801) also has a significant association with access to finance and hence, reject the null hypothesis at the $0.05 \%$ and accepted alternate hypothesis. When the education is increase by 0.589 units, there is an increase in the access to loan by the owner and manager of SMEs. As the entrepreneur (owner-manager) of SMEs have more education, they can easily get the business's financing compared to the individual who has less education. The banking and other financial institutions hesitate and did not encourage the owner 
and manager of SMEs to have less educated for credit opportunities than the educated ownermanager of SMEs.

Although the gender, experience and skills of an entrepreneur (owner-manager) of SMEs are the important personal traits and impact the business decisions, including financing and external sources for getting funds for the SMEs. Nevertheless, in the present study, gender, experience and skills have not been signed, and the P-value is $(0.995,0.459$ and 0.535$)$ respectively, and did not reject the null hypotheses at $1 \%, 5 \%$, and $10 \%$ significance and accepted the alternate hypotheses. It means that these three factors have no significant relation to finance access in the current study.

The likelihood ratio test value is 29.468 with a P-value of 0.000 , which indicated that the overall goodness of fit of the model is good and statistically significant. The value of Cox and Snell Rsquare is 0.694 , and Nagelkerke R-square is 0.941 , which shows that the model is good and explained the changes between $69.4 \%$ to $94.1 \%$ in the dependent variable by the explanatory variables in the model. The higher the values of these, the better is the model.

In table 4, the Hosmer-Lemeshow test shows the goodness of fit of the model; the higher the value of the test, the better fitted the model. The value of the test is (Chi-square 2.248(8), 0.945), it means that predictive quality of the model and it resulted in a correctly predicting and the value is $94.5 \%$, which is a very high value and close to 1 ; thus the model has high goodness of fit. Based on the Omnibus test, the corresponding Chi-square value is reported 227.437 with 8 degrees of freedom with $\mathrm{p}$-value $(\mathrm{P}<0.0001)$, so the explanatory variables used in the model are significantly contributed as compared to the model where the predictors are not used.

\section{Table 4}

Binary logistic regression model results

\begin{tabular}{|c|c|c|c|c|c|c|}
\hline & B & S.E. & Wald & df & Sig. & $\operatorname{Exp}(B)$ \\
\hline Age & 1.703 & 0.439 & 15.024 & 1 & 0.000 & 5.488 \\
\hline Gender & 23.732 & 416.882 & 0.001 & 1 & 0.995 & 20657.2 \\
\hline Education & 0.589 & 0.287 & 4.22 & 1 & 0.040 & 1.801 \\
\hline Experience & 0.239 & 0.323 & 0.548 & 1 & 0.459 & 1.27 \\
\hline Skills & -0.643 & 1.035 & 0.385 & 1 & 0.535 & 0.526 \\
\hline Constant & -30.697 & 416.884 & 0.012 & 1 & 0.994 & 0 \\
\hline-2 Log likelihood & 29.468 & & & & & \\
\hline Cox \& Snell R Square & 0.694 & & & & & \\
\hline Nagelkerke R Square & 0.941 & & & & & \\
\hline
\end{tabular}

\section{Hosmer and Lemeshow GOF Test}

Chi-square (df)

\section{Omnibus Tests of Model}

Chi-square(df) $227.437(8) * * *$

Variable(s) entered: Age, Gender, Education, Experience, Skills. 
Table 5 is about the classification table shows the dependent variable (access to finance) having yes or no option. The classification table is another way of estimating the accuracy of the logistic regression model. This table contains the observed values (user-defined cut-off value, for example, $\mathrm{p}=0.50$ ) for dependent results and predicted values. This table shows the individual's percentage of the choice of the variable's answer in the model. The overall percentage of the model is $95.31 \%$ which shows that the model is good and accurate.

Table 5

Classification Table

\begin{tabular}{llccl}
\hline & & \multicolumn{3}{l}{ Predicted } \\
\cline { 3 - 5 } Observed & & Access to finance & \\
\cline { 3 - 5 } Do you have access to finance? & No & 71 & Yes & Percentage Correct \\
\cline { 3 - 5 } & Yes & 5 & 112 & 94.67 \\
& Overall Percentage & & & 95.31 \\
\hline
\end{tabular}

The cut value is .500

\section{Discussions and Conclusions}

The results of the binary regression analysis show that age and education are the two variables with significant results at $1 \%$ and $5 \%$ of significance level and reject the null hypotheses at $1 \%$ and 5\%. These results are similar to (Aosa, 2012; Eniola \& Entebang, 2017; Kamau Ng'ang'a, Ngugi, \& Odhiambo, 2014; Rafiki, 2020; Woldie, Leighton, \& Adesua, 2008; Zabri, Ahmad, \& Lean, 2015), Who have also reported the same findings in their studies about a significant association of age and experience of entrepreneurs and their access to loan.

Although the gender, experience and skills of an entrepreneur (owner-manager) of SMEs are the important personal traits and impact the business decisions, including financing and external sources for getting funds for the SMEs. However, in the present study, gender, experience, and skills have no significant relation to finance access in the current study. These results are similar to the studies (Brana, 2013; Campanella \& Serino, 2019; Constantinidis, Cornet, \& Asandei, 2006; Makani, Lestina, \& Ewane, 2020; Rafiki, 2020).

Financial institutions are usually reluctant to lend for the startups because of the high risks of loan, financial institutions are more likely they know the customers well. Another personal aspect of the problem may be that credit officials as a group of clients can pose a threat to women entrepreneurs they know very little. Many banks' marketing strategies are based on a user profile that may not be suitable for female business people (for example, the ability to access banks or be available during business hours). Facing cultural barriers that women entrepreneurs face, e.g., maximize mobility and time demands, further limit women $r$ ability to access finance.

Some studies have mixed results regarding the entrepreneurial specific characteristics and access to finance. A study Wachira and Kihiu (2012) reveals that education and loan accessibility in Kenya and resulted that access to loan is not related to knowledge of financing but related to income level, age, marital status, gender, and education. A study by Ogubazghi and Muturi (2014) 
examined that owner-manager's age has a relation with access to loans for SMEs. On the other hand, access to bank loans has no significant effect on the educational level.

It is concluded that different factors related to the firm's entrepreneur (owner-manager of SMEs) are influencing the financing and credit availability from the financial institutions operating in the country and specifically in the Khyber Pakhtunkhwa. The entrepreneur's factors like educational background, experiences, professional skills, age, and gender influence the SMEs business operations. All these personal traits of SME's entrepreneur are important in its operations and especially in getting the financing from the external sources for the SMEs in KP. It summarized that age and experience, both the unique features of the entrepreneur of SMEs, are significantly positively associated with the access to financing for the external sources, including formal and informal banking and financial institutions who deal in providing the funds to the businesses in the KP. On the other hand, other factors, education and skills of the owner-manager of SMEs, are insignificant with the access to financing. Although these factors also play an important role, this study resulted that these are not relevant in SMEs working in KP.

\section{References}

Abdoli, G., Tajik, H., Ghasemi, E., \& Jamali, B. (2012). A survey on how different factors impact entrepreneurs' success in food industry. Management Science Letters, 2(7), 2631-2636.

Abdullah, M. A., Manan, A., \& Khadijah, S. (2011). Small and Medium Enterprises and Their Financing Patterns: Evidence from Malaysia. Journal of Economic Cooperation \& Development, 32(2), 1-18.

Ahmad, N. H. (2007). A cross cultural study of entrepreneurial competencies and entrepreneurial success in SMEs in Australia and Malaysia.

Ahmed, H., \& Hamid, N. (2011). Financing constraints: determinants and implications for firm growth in Pakistan. The Lahore Journal of Economics, 16, 317.

Akoten, J. E., Sawada, Y., \& Otsuka, K. (2006). The determinants of credit access and its impacts on micro and small enterprises: The case of garment producers in Kenya. Economic development and cultural change, 54(4), 927-944.

Aosa, E. (2012). Upper Echelons Theory and Research: A review of Theory and Empirical Literature 28 Years Later. Journal of Business Administration and Management 2(10), 697-703.

Arshad, M., \& Arshad, D. (2019). Internal capabilities and SMEs performance: A case of textile industry in Pakistan. Management Science Letters, 9(4), 621-628.

Assimakopoulos, D., \& Mitussis, D. (2010). SME innovation in Zhejiang, China. Journal of Knowledge-based Innovation in China, 2(1), 89-105.

Beck, T. (2007). Financing constraints of SMEs in developing countries: Evidence, determinants and solutions. Paper presented at the KDI 36th Anniversary International Conference.

Beck, T., \& Demirguc-Kunt, A. (2006). Small and medium-size enterprises: Access to finance as a growth constraint. Journal of Banking \& finance, 30(11), 2931-2943.

Brana, S. (2013). Microcredit: an answer to the gender problem in funding? Small Business Economics, 40(1), 87-100.

Budhi, M., Lestari, N., Suasih, N., \& Wijaya, P. (2020). Strategies and policies for developing SMEs based on creative economy. Management Science Letters, 10(10), 2301-2310.

Campanella, F., \& Serino, L. (2019). Do personal characteristics of manager affect Smes' Access to Bank Loan. International Journal of Economics, Business and Finance, 6(2), 1-14. 
Coleman, S. (2004). The Role of Education and Experience in Small Firm Access to Bank Loans: Is There a Link? Journal of Business and Entrepreneurship, 16(1), 1-16.

Constantinidis, C., Cornet, A., \& Asandei, S. (2006). Financing of women-owned ventures: The impact of gender and other owner-and firm-related variables. Venture Capital, 8(02), 133157.

Eniola, A. A., \& Entebang, H. (2017). SME managers and financial literacy. Global Business Review, 18(3), 559-576.

Fatoki, O., \& Odeyemi, A. (2010). Which new small and medium enterprises in South Africa have access to bank credit? International Journal of Business and Management, 5(10), 128-136.

Gompers, P., Kovner, A., Lerner, J., \& Scharfstein, D. (2010). Performance persistence in entrepreneurship. Journal of financial economics, 96(1), 18-32.

Harvies, C. (2008). SME Development Strategies in Vietnam, Small and Medium Sized Enterprises in East Asia. The Role of SMEsin National Economies in East Asia, 194-231.

Headd, B. (2003). Redefining business success: Distinguishing between closure and failure. Small Business Economics, 21(1), 51-61.

Irwin, D., \& Scott, J. M. (2010a). Barriers faced by SMEs in raising bank finance. International Journal of Entrepreneurial Behavior \& Research, 16(3), 245-259.

Irwin, D., \& Scott, J. M. (2010b). Barriers faced by SMEs in raising bank finance. International Journal of Entrepreneurial Behavior \& Research 16(3), 245-259.

Kamau Ng'ang'a, P., Ngugi, P. K., \& Odhiambo, R. (2014). Influence of owner/manager personal characteristics on the demand for business development services by micro and small enterprises: Perspectives from the upper echelons theory. International Journal of Business and Social Science, 5(6), 108-114.

Kasseeah, H., \& Thoplan, R. (2012). Access to financing in a small island economy: Evidence from Mauritius. Journal of African business, 13(3), 221-231.

Kira, A. R. (2013). The evaluation of the factors influence the access to debt financing by Tanzanian SMEs. 5, 1-24.

Le, N. T., Venkatesh, S., \& Nguyen, T. V. (2006). Getting bank financing: A study of Vietnamese private firms. Asia Pacific Journal of Management, 23(2), 209-227.

Makani, S. R., Lestina, N. M., \& Ewane, S. C. (2020). Characteristics of owner-managers of cameroonian family SMEs and access to bank credit. Research Journal of Finance and Accounting, 11(12), 15-27.

Midi, H., Sarkar, S. K., \& Rana, S. (2010). Collinearity diagnostics of binary logistic regression model. Journal of Interdisciplinary Mathematics, 13(3), 253-267.

Mijid, N. (2009). Gender, race, and credit rationing of small businesses: Empirical evidence from the 2003 Survey of Small Business Finances: Colorado State University.

Muenjohn, N., \& McMurray, A. (2017). Design leadership, work values ethic and workplace innovation: an investigation of SMEs in Thailand and Vietnam. Asia Pacific Business Review, 23(2), 192-204.

Mukiri, W. G. (2011). Determinants of access to Bank credit by micro and small enterprises in Kenya. Beacon Consultant Service.

Murphy, K. M., Shleifer, A., \& Vishny, R. W. (1989). Industrialization and the big push. Journal of political economy, 97(5), 1003-1026. 
Nguyen, N., \& Luu, N. (2013). Determinants of financing pattern and access to formal-informal credit: the case of small and medium sized enterprises in Viet Nam. Journal of Management Research, 5(2), 240-259.

Nimalathasan, B. (2008). A relationship between owner-manager's characteristic and business performance. LESIJ-Lex ET Scientia International Journal, 15(1), 61-68.

Nofsinger, J. R., \& Wang, W. (2011). Determinants of start-up firm external financing worldwide. Journal of Banking \& Finance, 35(9), 2282-2294.

Ogubazghi, S. K., \& Muturi, W. (2014). The effect of age and educational level of owner/managers on SMMEs' access to bank loan in Eritrea: evidence from Asmara City. American Journal of Industrial and Business Management, 4(11), 632-643.

Pandula, G. (2011). An Empirical Investigation of Small and Medium Enterprise's Acces to Bank Finance. Paper presented at the ASBBS Annual Conference Proccedding.

Pinkovtskaia, I. S., Balynin, I., Arbeláez Campillo, D. F., \& Rojas-Bahamón, M. (2019). Small business development in Russia: results of the assessment of sectoral structure and number of employees. Espacios, 40(7), 6.

Rafiki, A. (2020). Determinants of SME growth: an empirical study in Saudi Arabia. International Journal of Organizational Analysis, 28(1), 205-225.

Rand, J. (2007). Credit constraints and determinants of the cost of capital in Vietnamese manufacturing. Small Business Economics, 29(1-2), 1-13.

Romano, C. A., Tanewski, G. A., \& Smyrnios, K. X. (2001). Capital structure decision making: A model for family business. Journal of business venturing, 16(3), 285-310.

Saparito, P., Elam, A., \& Brush, C. (2013). Bank-firm relationships: do perceptions vary by gender? Entrepreneurship Theory and Practice, 37(4), 837-858.

Simpson, M., Tuck, N., \& Bellamy, S. (2004). Small business success factors: the role of education and training. Education + Training, 46(8/9), 481-491.

Slavec, A., \& Prodan, I. (2012). The influence of entrepreneur's characteristics on small manufacturing firm debt financing. Journal for East European Management Studies, 104130.

Sweet, S. A. (2011). Data analysis with Spss + mysearchlab with etext: A first course in applied statistics: Prentice Hall.

Thomas, A. S., \& Mueller, S. L. (2000). A case for comparative entrepreneurship: Assessing the relevance of culture. Journal of international business studies, 31(2), 287-301.

Uddin, M. R., \& Bose, T. K. (2013). Factors affect the success of SME in Bangladesh: Evidence from Khulna City. J. Mgmt. \& Sustainability, 3(3), 166.

UNDP, M. (2007). Malaysia: Small and medium enterprises building an enabling environment. Kuala Lumpur: United Nations Development Programme.

Vos, E., Yeh, A. J.-Y., Carter, S., \& Tagg, S. (2007). The happy story of small business financing. Journal of Banking \& Finance, 31(9), 2648-2672.

Wachira, I. M., \& Kihiu, E. N. (2012). Impact of financial literacy on access to financial services in Kenya. International Journal of Business and Social Science, 3(19), 42-50.

Watson, J., Newby, R., \& Mahuka, A. (2009). Gender and the SME "finance gap". International Journal of Gender and Entrepreneurship, 1(1), 42-56.

Woldie, A., Leighton, P., \& Adesua, A. (2008). Factors influencing small and medium enterprises (SMEs): an exploratory study of owner/manager and firm characteristics. Banks and Bank Systems, 3(3), 5-13. 
Yaldiz, E., Altunbas, Y., \& Bazzana, F. (2011). Determinants of informal credit use: A cross country study. Paper presented at the Midwest Finance Association 2012 Annual Meetings Paper.

Zabri, S. M., Ahmad, K., \& Lean, J. (2015). Understanding owner-managers' preferences towards different sources of financing: The case of successful SMEs in Malaysia. Advanced Science Letters, 21(5), 1435-1438.

Zarook, T., Rahman, M. M., \& Khanam, R. (2013). Management skills and accessing to finance: evidence from Libya's SMEs. International Journal of Business and Social Science, 4(7), $106-115$. 